\title{
DAMPAK BANTUAN PROGRAM CORPORATE SOCIAL RESPONSIBILITY (CSR) PT AGRICON TERHADAP PENDAPATAN/KESEJAHTERAAN PETANI JAGUNG DI BOGOR, JAWA BARAT
}

\section{CONCUSSION ON CORPORATE SOCIAL RESPONSIBILITY (CSR) AID PROGRAM FROM PT. AGRICON FOR CORN FARMER'S WELFARE IN BOGOR, WEST JAVA}

\author{
Azhar $^{1}$ \\ 1Jurusan Pertanian, Politeknik Pembangunan Pertanian (POLBANGTAN) Bogor. \\ JI Aria Surialaga No. 1. Bogor, Jawa Barat. \\ *Korespondensi penulis, Email: azhar.feb1960@gmail.com
}

Diterima: Desember 2019

Disetujui terbit: April 2020

\begin{abstract}
This study is to know the effect of the implementation of company's CSR program to poverty reduction in rural areas, namely the income of farmers who received Corn Silage CSR Program of PT Agricon. The research location is the working area of PT Agricon in Tangerang District, Banten Province at Gajlug Village and Bantar Kambing Village. This researh is an explanatory study and correlational survey method. The result showed a positive correlation illustrating the variable PT Agricon CSR Program, Corporate Image, Public Participation and Empowerment Process can improve Farmers Welfare.
\end{abstract}

Keywords: CSR, farmer, welfare

\begin{abstract}
ABSTRAK
Penelitian ini menstudi tentang pengaruh bentuk implementasi program CSR perusahaan terhadap penurunan tingkat kemiskinan di pedesaan yaitu pendapatan petani yang mendapatkan program CSR Jagung Silase dari PT Agricon. Lokasi penelitian adalah Wilayah kerja PT Agricon di Desa Gajlug, Kabupaten Tangerang, Provinsi Banten serta Kabupaten Bogor yaitu di Desa Bungur dan Desa Bantar Kambing, Kecamatan Ciseeng. Penelitian ini bersifat explanatory study dan korelasional dengan metode survei. Hasil penelitian menunjukkan korelasi positif yang menggambarkan bahwa variabel Program CSR PT Agricon, citra perusahaan, partisipasi masyarakat dan proses pemberdayaan dapat meningkatkan kesejahteraaan petani.
\end{abstract}

Kata kunci: CSR, petani, kesejahteraan 


\section{PENDAHULUAN}

\section{Latar Belakang}

Dalam pelaksanaan kegiatan usaha seringkali perusahaan memiliki dampak negatif terhadap para stakeholders seperti kesenjangan sosial dan kerusakan lingkungan. Pihak perusahaan dalam menanggapi dampak negatif tersebut diwajibkan untuk membuat sebuah komitmen yang telah disepakati bersama yang dikenal dengan Tanggung jawab Sosial Perusahaan atau Corporate Social Responsibility (selanjutnya akan ditulis dengan CSR).

Merujuk pada pendapat Sukada et al. (2007) CSR didefinisikan sebagai segala upaya manajemen yang dijalankan entitas bisnis untuk mencapai tujuan pembangunan berkelanjuta berdasar keseimbangan pilar ekonomi, sosial, dan lingkungan (triple bottom lines) dengan meminimumkan dampak negatif dan memaksimalkan dampak positif di setiap pilar.

Penerapan CSR juga dapat berfungsi sebagai jembatan hubungan yang harmonis antara perusahaan dan lingkungannya.

Menurut Mapisangka (2009) di antara ribuan perusahaan yang ada diindikasikan belum semua perusahaan benar-benar menerapkan konsep CSR dalam kegiatan perusahaannya.

Mapisangka (2009) juga menjelaskan bahwa dalam lingkungan bisnis perusahaan, masyarakat di sekitar perusahaan pada dasarnya merupakan pihak yang perlu mendapatkan apresiasi yang dapat diwujudkan dalam bentuk peningkatan kesejahteraan hidup mereka melalui kegiatan pemberdayaan masyarakat oleh pihak CSR perusahaan.

Menurut Saidi et al. (2003) sumbangan sosial perusahaan memiliki dua dimensi yaitu karitas (charity) dan filantropi, dimana karitas adalah bantuan yang sifatnya sesaat, sedangkan filantropi adalah sumbangan yang ditujukan untuk kegiatan investasi sosial atau kegiatan yang diarahkan pada penguatan kemandirian masyarakat.

Keberhasilan suatu program CSR yang dijalankan suatu perusahaan tidak hanya dapat memberikan dampak yang positif bagi perusahaan saja, tetapi juga pada komunitas lokal setempat yang dapat dicirikan dengan penurunan tingkat kemiskinan pada masyarakat. Kemiskinan telah menjadi sebuah permasalahan yang banyak terjadi di Indonesia.

Menurut data BPS, pada bulan Maret 2015, jumlah penduduk miskin di Indonesia mencapai 28,59 juta orang atau sebesar 11,22 persen, bertambah sebesar 0,86 juta orang dibandingkan dengan kondisi September 2014 yang sebelumnya sebesar 27,73 juta orang atau 10,96 persen.

Berdasarkan hal tersebut, pertanyaan yang akan dibahas pada 
penulisan penelitian ini adalah bagaimana pengaruh bentuk implementasi program CSR perusahaan terhadap penurunan tingkat kemiskinan di pedesaan.

Tujuan penelitian ini adalah menstudi konsep program CSR yang telah dilaksanakan PT Agricon. Kemudian, menstudi dampak program CSR PT Agricon terhadap pendapatan dan penurunan tingkat kemiskinan petani jagung di Kabupaten Bogor.

\section{METODE PENELITIAN}

Penelitian ini dilaksanakan pada Bulan Mei 2018 hingga Desember 2018. Lokasi penelitian adalah Wilayah kerja PT Agricon di Kabupaten Tanggerang, Desa Gajlug Provinsi Banten serta Kabupaten Bogor yaitu di Kecamatan Ciseeng Desa Bungur dan Desa Bantar Kambing.

Penelitian ini tidak dilakukan intervensi dan kontrol terhadap variabelvariabel seperti yang normatif dilakukan dalam sebuah penelitian eksperimen. Pengujian model teroritis dilakukan dengan cara menganalisis hubungan pengaruh antar variabel di dalam model, melalui pengujian statistik terhadap hipotesis berdasarkan hasil penelitian di lapang. Penelitian ini menelaah secara kuantitatif yang bersifat explanatory study dan korelasional.

Populasi penelitian ini adalah seluruh masyarakat yang terkait dalam kegiatan CSR perusahaan PT Agricon di Kabupaten Bogor Jawa Barat. Menurut informasi pihak perusahaan yang ada pada perusahaan tahun 2015, untuk kegiatan CSR pada kelompok masyarakat yang mengusahakan komoditi jagung terdapat di 1 kecamatan, pada 2 desa binaan perusahaan.

Dari kedua Desa diketahui bahwa jumlah kelompok tani yang mendapatkan program CSR dari PT Agricon adalah dua kelompok dengan jumlah anggota keseluruhan 50 anggota. Untuk itu maka, penelitian ini menggunakan metode survei dalam pengambilan datanya dengan keseluruhan anggota menjadi sampel penelitian.

Variabel penelitian antara lain program CSR perusahaan (X1), citra perusahaan di mata masyarakat, partisipasi masyarakat dalam pemberdayaan melalui CSR perusahaan, proses pemberdayaan masyarakat melalui CSR perusahaan, dan keberdayaan penilaian hasil pemberdayaan melalui CSR (peningkatan pendapatan).

Pengumpulan Data Awal dilakukan untuk melakukan pengujian alat ukur sebelum disebarkan pada responden yang menjadi sampel sebenarnya dalam penelitian ini. Setelah itu dilakukan penyusunan kuesioner pendahuluan sebagai pre-test, guna mendapatkan kuesioner yang valid dan representatif bagi tahap penelitian 
selanjutnya. Kuesioner awal disebarkan kepada responden yang mempunyai karakteristik sama dengan calon responden dalam sampel penelitian.

Kuesioner penelitian diuji validitas dan reliabilitasnya. Validitas menunjukkan tingkat kemampuan instrumen penelitian mengukur apa yang diinginkan dan dapat mengungkapkan data dan variabel yang diteliti secara tepat (Singarimbun dan Effendi, 1995). Pengujian validitas dilakukan dengan analisa butir. Sebuah instrumen dikatakan valid, jika koefisien korelasinya $>0,3$ dengan a 0,05. (Sugiyono, 2001). Untuk menguji validitas responden digunakan rumus korelasi "product moment".

$$
r=\frac{n \Sigma x y-\Sigma x \Sigma y}{\sqrt{\left(n \Sigma x^{2}-(\Sigma x)^{2}\right)\left(n\left(\Sigma y^{2}\right)-(\Sigma y)^{2}\right)}}
$$

Dimana:

$r=$ koefisien korelasi

$\mathrm{x}=$ skor jawaban tiap item

$y=$ skor total

$\mathrm{n}=$ jumlah responden

Jika $t_{\text {hitung }}>t_{\text {tabel, }}$, berarti valid

Jika $t_{\text {hitung }}<t_{\text {tabel, }}$, berarti tidak valid

Uji reabilitas atau keterandalan mengarah pada keajegan suatu alat ukur, dimana tingkat keterandalan memperhatikan sejauh mana alat ukur dapat diandalkan dan dipercaya (Singarimbun dan Effendi, 1995). Uji realiabilitas instrumen penelitian ini menghasilkan alpha yang telah dibakukan (standarized item alpha) dan nilai alpha ini harus lebih besar dari keterandalan yang diijinkan dihubungkan dengan jumlah butir pertanyaan yang ada pada kuesioner.

Upaya peningkatan reliabilitas instrumen, terutama dalam proses mempersiapkan dan mengembangkan instrumen serta pada waktu kita menggunakan instrumen tersebut untuk menyaring data. Uji reliabilitas instrumen dilakukan dengan melihat koefisien Alpha Cronbach, dan jika a $>0,5$ maka instrumen penelitian dikatakan reliabel.

\section{Teknik Analisis Data}

Teknik Analisis jalur dapat membantu para peneliti untuk menentukan apakah hubungan antara variabel-variabel itu terjadi secara langsung atau melalui variabel antara dan juga dapat membandingkan besar kecilnya pengaruh, baik yang langsung maupun yang tidak langsung. Langkahlangkah untuk menghitung koefisien jalur adalah sebagai berikut:

1. Membuat diagram jalur

Pengaruh langsung antara variabel-variabel dari gambar diagram jalur (Solimun, 2002). Untuk mencari pengaruh tidak langsung antara variabel dicari dengan mengalikan koefisien path $(\beta)$.

2. Pengujian Hipotesis 


$$
\text { Gujarati (1999) menjelaskan }
$$

bahwa untuk melakukan pengujian regresi linier berganda terstandarisasi yang memiliki pengaruh langsung, maka digunakan, uji $\mathrm{t}$ (individual test). Uji $\mathrm{t}$ digunakan untuk menguji tingkat pengaruh secara parsial variabel eksogen terhadap variabel endogen

Tingkat kesalahan yang dapat ditolelir pada penelitian ini adalah 0,05 atau 5\%. Jika $\mathrm{P}$ value $<\mathrm{a}$, maka $\mathrm{H}_{0}$ ditolak atau $\mathrm{H}_{1}$ diterima. Berarti secara parsial variabel eksogen berpengaruh nyata terhadap variabel endogen pada tingkat kesalahan 0,05 atau $5 \%$.

Untuk membantu mempercepat dan mengurangi resiko kesalahan perhitungan, peneliti menggunakan software perhitungan statistik yaitu SPSS versi 20. Dengan software ini, peneliti mengharapkan resiko kesalahan dapat diminimalisir sehingga hasil perhitungan lebih dapat dipertanggungjawabkan.

\section{Hipotesis}

Dari kerangka berpikir, dapat dikemukakan hipotesis kerja sebagai berikut:

1. Hipotesis 1, Program CSR

Perusahaan (X1) berpengaruh positif terhadap Partisipasi Masyarakat dalam Pemberdayaan melalui CSR Perusahaan (X3).

2. Hipotesis 2, Citra Perusahaan di Mata Masyarakat (X2) berpengaruh positif terhadap Partisipasi Masyarakat dalam Pemberdayaan melalui CSR Perusahaan (X3).

3. Hipotesis 3, Partisipasi Masyarakat dalam Pemberdayaan melalui CSR Perusahaan (X3) berpengaruh positif terhadap Proses Pemberdayaan Masyarakat melalui CSR Perusahaan (X4).

4. Hipotesis 4, Proses Pemberdayaan Masyarakat melalui CSR Perusahaan (X4) berpengaruh positif terhadap Keberdayaan penilaian hasil pemberdayaan melalui CSR (Peningkatan Pendapatan) (Y).

\section{HASIL DAN PEMBAHASAN}

\section{Profil Anggota Kelompok \\ Peserta Program CSR PT Agricon}

Profil anggota kelompok yang menjadi peserta Program CSR PT Agricon dapat dijelaskan berdasarkan data:

a. Usia

Usia rata-rata peserta adalah 42,16 tahun sehingga dapat dikatakan sebagian besar peserta ada pada usia produktif. Keragaan peserta berdasarkan usia dapat dilihat pada gambar berikut. 


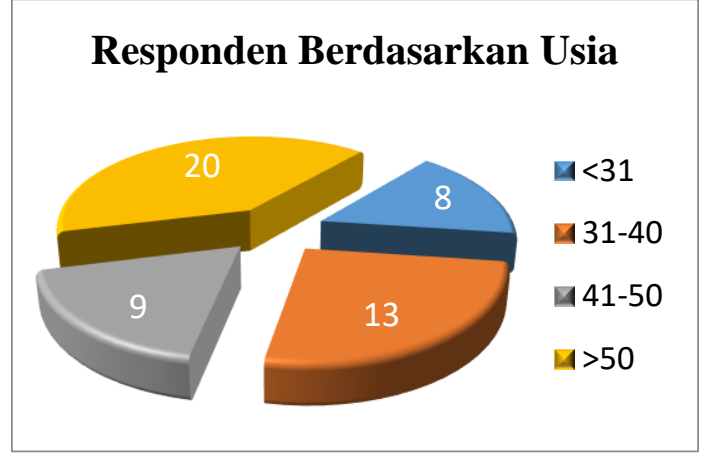

Gambar 1. Responden Berdasarkan

Usia

Dari Gambar 1 diketahui bahwa 30 orang peserta masih berusia dibawah 51 tahun. Hal ini menunjukkan bahwa petani/peternak pada kelompok tani peserta program CSR PT Agricon masih berusia muda.

b. Tingkat Pendidikan

Berdasarkan data hasil survei diketahui sebagian besar tingkat pendidikan peserta rata rata adalah lulusan SLTA yaitu sebanyak 20 orang. Keragaan tingkat pendidikan peserta dapat dilihat sebagai berikut.

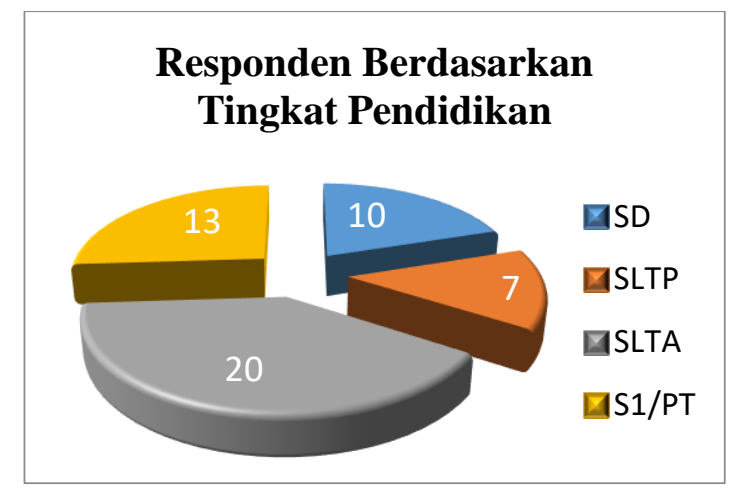

Gambar 2. Responden Berdasarkan

Tingkat Pendidikan

c. Jenis Kelamin

Berdasarkan jenis kelamin diketahui bahwa peserta didominasi oleh pria sejumlah 42 orang. Peserta perempuan yang ikut dalam Program CSR PT Agricon adalah sejumlah 8 orang.

d. Pekerjaan Utama

Pekerjaan utama sebagian besar peserta program CSR PT Agricon adalah Petani sejumlah 33 orang. Pekerjaan berikutnya yaitu sebagai Peternak sejumlah 11 orang. Diketahui juga bahwa ada 6 peserta yang memiliki pekerjaan utama sebagai Buruh. Buruh dalam hal ini adalah orang yang bekerja kepada pemilik lahan/ternak. Keragaan responden berdasarkan pekerjaan utama dapat dilihat pada gambar berikut.

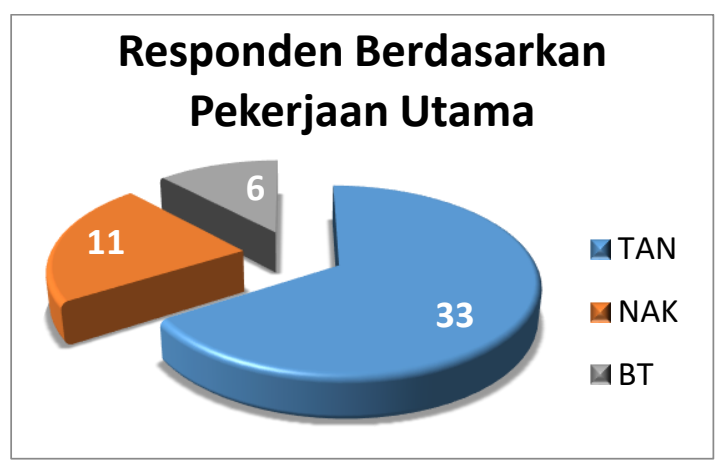

Gambar 3. Responden Berdasarkan Pekerjaan Utama

e. Tingkat Pendapatan

Dari survei lapangan diketahui bahwa masih cukup banyak responden yang memiliki pendapatan rendah $(<R p$ 1.500.000,-) yaitu sejumlah 19 orang. Responden yang memiliki pendapatan tinggi (> Rp 3.000.000,-) yaitu hanya sejumlah dua orang. Keragaan tingkat pendapatan responden dapat dilihat sebagai berikut. 


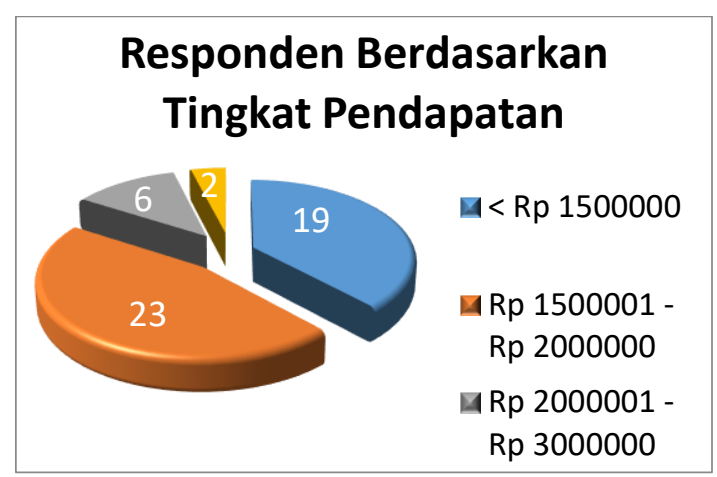

Gambar 4. Responden berdasarkan tingkat pendapatan

f. Luasan dan Kepemilikan Lahan Garapan

Dari hasil crosstabulation data luasan dan kepemilikan lahan garapan diketahui terdapat tiga orang responden yang memiliki dan menggarap lahan seluas 0,3 ha. Ada pula satu orang responden yang memiliki dan menggarap lahan seluas 1,5 ha. Hal ini menunjukkan adanya ketimpangan kepemilikan lahan yang cukup besar.

Keragaan responden berdasarkan luasan dan status kepemilikan lahan garapan dapat dilihat pada gambar 5 dan gambar 6.

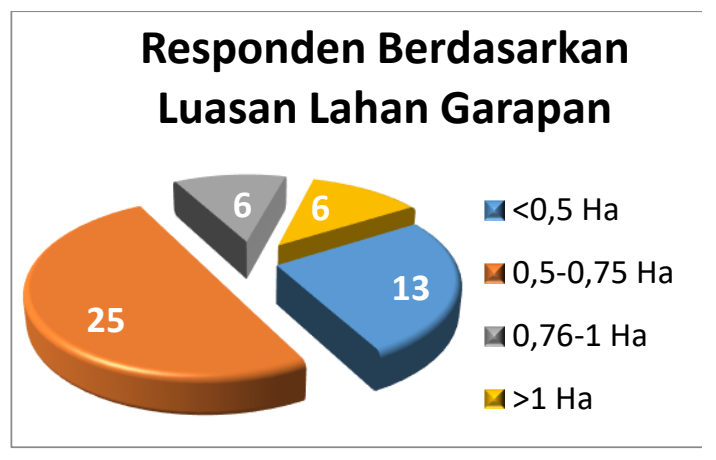

Gambar 5. Responden Berdasarkan Luasan Lahan Garapan

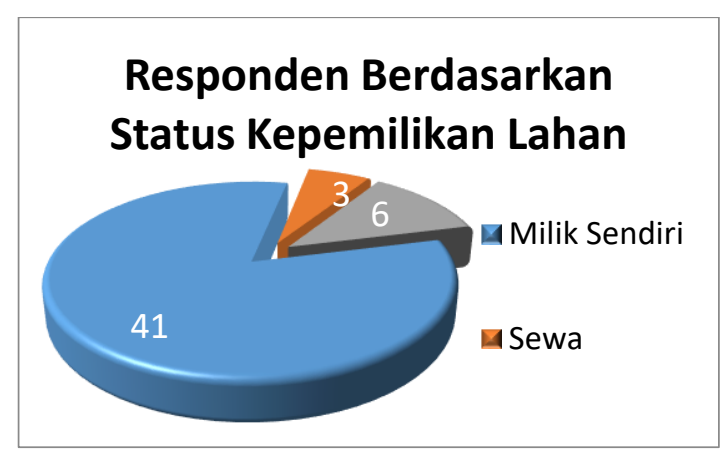

Gambar 6. Responden Berdasarkan

Status Kepemilikan Lahan

\section{Konsep Program CSR PT Agricon}

Salah satu bentuk dari program CSR yang dilaksanakan PT Agricon adalah Jagung Silase. Program ini dibentuk sebagai upaya pemberdayaan petani jagung dan juga peternak di wilayah sekitar perusahaan. Bentuk dari program ini adalah pemberdayaan petani dan peternak dalam menyediakan pakan hijauan bagi ternak yang berbahan dasar jagung silase.

$$
\text { Morrison (1961) menjelaskan }
$$

bahwa silase adalah pakan ternak awetan yang umumnya dibuat dari hijauan, limbah pertanian, limbah rumah potong/limbah industri, ikon dengan menggunakan proses fermentasi asam laktat. Banyak literatur yang menjelaskan bahwa silase yaitu pakan ternak yang masih tinggi kadar air dan merupakan hasil pengawetan hijauan makanan ternak atau bahan-bahan lain melalui proses fermentasi dalam kondisi anaerob baik dengan penambahan atau 
tanpa penambahan bahan pengawet. Dengan demikian, jagung silase dapat diartikan sebagai pakan ternak silase yang berbahan dasar tanaman jagung.

Program CSR yang dilaksanakan oleh PT Agricon tidak hanya menyampaikan bagaimana membuat silase berbahan tanaman jagung. Petani diharapkan mampu dan mau membudidayakan tanaman jagung untuk menjadi bahan silase. Untuk itu kegiatan pemberdayaan yang dilakukan oleh PT Agricon adalah dengan memberikan bimbingan dan pelatihan budidaya jagung silase hingga teknik pembuatan silase tersebut.

Sebagai usaha untuk memotivasi petani agar mau membudidayakan tanaman jagung bahan silase, PT Agricon tidak hanya membantu menyediakan benih tetapi juga pupuk dan pestisida. Selain itu, PT Agricon juga memberikan jaminan akan membeli baik tanaman jagung hasil budidaya tersebut maupun produk olahnnya yang telah menjadi silase.

Konsep memandirikan petani dari program ini adalah pemberian pengetahuan dan keterampilan kepada petani sehingga memiliki kemampuan dan kemauan untuk berusaha. Hal ini dilakukan dalam kegiatan-kegiatan pertemuan dan fasilitasi. Dengan pengetahuan dan keterampilan tersebut, PT Agricon mengharapkan petani dapat melakukannya secara mandiri setelah program CSR PT Agricon berakhir.

Selain untuk memandirikan Petani dalam berusaha, PT Agricon juga mempunyai tujuan lain dalam program CSR ini yaitu untuk mendukung upaya pemerintah $\mathrm{RI}$ dalam upaya penyediaan pakan ternak organik dan bernutrisi tinggi. Penyediaan pakan ternak tersebut diharapkan dapat meningkatkan produksi ternak di Indonesia sehingga program pemerintah dalam usaha swasembada daging dapat terwujud.

\section{Hasil Perhitungan Korelasi}

Dari pengolahan data menggunakan SPSS ver. 20 diperoleh hasil seperti pada di bawah. Tabel 2 menunjukkan bahwa Program CSR memiliki pengaruh nyata positif terhadap Citra Perusahaan sebesar 0,615 pada tingkat kesalahan sebesar $1 \%$.

Hasil ini menunjukkan bahwa program CSR yang selama ini telah dilaksanakan oleh PT Agricon meningkatkan citra PT Agricon di mata masyarakat. Dengan meningkatnya citra perusahaan di mata masyarakat maka kepercayaan masyarakat terhadap PT Agricon dan produk-produk yang dihasilkannya juga meningkat. Peningkatan ini akan memberikan dampak positif terhadap penjualan produk PT Agricon. 
Tabel 2. Korelasi antara Program CSR, Masyarakat, Proses Pemberdayaan dan Citra Perusahaan, Partisipasi Peningkatan Kesejahteraan

Correlations

\begin{tabular}{|c|c|c|c|c|c|c|}
\hline & & $\begin{array}{l}\text { Program } \\
\text { CSR } \\
\end{array}$ & $\begin{array}{c}\text { Citra } \\
\text { Perusahaan }\end{array}$ & $\begin{array}{l}\text { Partisipasi } \\
\text { Masyarakat }\end{array}$ & $\begin{array}{c}\text { Proses } \\
\text { Pemberdayaan }\end{array}$ & $\begin{array}{l}\text { Peningkatan } \\
\text { Kesejahteraan }\end{array}$ \\
\hline \multirow{6}{*}{ Program CSR } & Pearson Correlation & 1 &, $615^{* \star}$ &, $561^{* *}$ & $464^{* *}$ &, $504^{* *}$ \\
\hline & Sig. (2-tailed) & &, 000 &, 000 & ,001 &, 000 \\
\hline & Sum of Squares & 20,862 & 17,088 & 9,180 & 7,828 & 9,325 \\
\hline & Covariance & 426 & .349 & .187 & .160 & 190 \\
\hline & $\mathrm{N}$ & 50 & 50 & 50 & & \\
\hline & Pearson Correlation & $615^{\star *}$ & 1 &, $563^{* *}$ & , $595^{* *}$ & ,616 \\
\hline \multirow{4}{*}{$\begin{array}{l}\text { Citra } \\
\text { Perusahaan }\end{array}$} & Sum of Squares & 17.088 & 37.050 & 12.267 & 13.373 & 15.190 \\
\hline & $\begin{array}{l}\text { and Cross-products } \\
\text { Covariance }\end{array}$ & 349 & .756 & 250 & 273 & 310 \\
\hline & $\mathrm{N}$ & 50 & 50 & 50 & 50 & 50 \\
\hline & $\begin{array}{l}\text { Pearson Correlation } \\
\text { Sig. (2-tailed) }\end{array}$ & $\begin{array}{r}, 561^{* *} \\
, 000\end{array}$ & $\begin{array}{r}, 563^{* *} \\
, 000\end{array}$ & 1 & $\begin{array}{r}, 737^{* *} \\
, 000\end{array}$ & $\begin{array}{r}, 638^{* *} \\
, 000\end{array}$ \\
\hline \multirow{4}{*}{$\begin{array}{l}\text { Partisipasi } \\
\text { Masyarakat }\end{array}$} & Sum of Squares & 9,180 & 12,267 & 12,814 & 9,742 & 9,253 \\
\hline & Covariance & , 187 & ,250 & ,262 & , 199 & 189 \\
\hline & $\mathrm{N}$ & 50 & 50 & 50 & 50 & 50 \\
\hline & $\begin{array}{l}\text { Pearson Correlation } \\
\text { Siq. (2-tailed) }\end{array}$ & $\begin{array}{r}, 464^{* *} \\
.001\end{array}$ & $\begin{array}{r}, 595^{* *} \\
.000\end{array}$ & $\begin{array}{r}, 737^{* *} \\
.000\end{array}$ & 1 & $\begin{array}{l}, 695^{* *} \\
.000\end{array}$ \\
\hline \multirow{5}{*}{$\begin{array}{l}\text { Proses } \\
\text { Pemberdayaan }\end{array}$} & $\begin{array}{l}\text { Sum of Squares } \\
\text { and Cross-products }\end{array}$ & 7,828 & 13,373 & 9,742 & 13,630 & 10,398 \\
\hline & Covariance & 160 & ,273 & , 199 & ,278 & ,212 \\
\hline & & 50 & 50 & 50 & 50 & 50 \\
\hline & Pearson Correlation &, $504^{\star \star}$ & $616^{* *}$ & ,638** & $695^{* *}$ & 1 \\
\hline & Sig. (2-tailed) &, 000 &, 000 &, 000 & ,000 & \\
\hline \multirow[t]{3}{*}{$\begin{array}{l}\text { Peningkatan } \\
\text { Kesejahteraan }\end{array}$} & $\begin{array}{l}\text { Sum of Squares } \\
\text { and Cross-products }\end{array}$ & 9,325 & 15,190 & 9,253 & 10,398 & 16,401 \\
\hline & Covariance & , 190 & ,310 & , 189 & ,212 & ,335 \\
\hline & $\mathrm{N}$ & 50 & 50 & 50 & 50 & 50 \\
\hline
\end{tabular}

**. Correlation is significant at the 0.01 level (2-tailed).

Sumber: Hasil olah data primer 
Program CSR PT Agricon juga memiliki pengaruh nyata positif terhadap partisipasi masyarakat dalam kegiatan CSR PT Agricon dimulai dari perencanaan hingga evaluasi kegiatan. Pengaruh nyata ini terlihat dari nilai koefisien korelasi Pearson sebesar 0,561 pada tingkat kesalahan sebesar $1 \%$. Hal ini menjawab Hipotesis 1 yaitu bahwa Program CSR Perusahaan (X1) berpengaruh positif terhadap Partisipasi Masyarakat dalam Pemberdayaan melalui CSR Perusahaan (X3). Dengan demikian dapat dikatakan bahwa semakin baik Program CSR yang dilaksanakan oleh PT Agricon maka akan semakin tinggi pula tingkat partisipasi peserta dalam kegiatan pemberdayaan pada CSR tersebut.

Citra Perusahaan memiliki pengaruh nyata positif terhadap Partisipasi masyarakat sebesar 0,563 dengan tingkat kesalahan sebesar $1 \%$. Hal ini menjawab Hipotesis 2 yaitu Citra Perusahaan di Mata Masyarakat (X2) berpengaruh positif terhadap Partisipasi Masyarakat dalam Pemberdayaan melalui CSR Perusahaan (X3). Dengan demikian dapat dikatakan bahwa Citra PT Agricon yang baik di mata masyarakat maka akan meningkatkan keinginan masyarakat untuk berpartisipasi dalam kegiatan pemberdayaan yang dilaksanakan oleh PT Agricon melalui program CSR-nya.

Dari data yang diolah menunjukkan bahwa Partisipasi Masyarakat memiliki pengaruh nyata terhadap Proses Pemberdayaan sebesar 0,737 dengan tingkat kesalahan sebesar $1 \%$. Nilai ini merupakan nilai korelasi yang paling tinggi pada korelasi antar variabel lainnya. Data ini dapat diartikan bahwa peningkatan partisipasi masyarakat dalam program CSR yang dilaksanakan PT Agricon dapat dipastikan akan meningkatkan keberhasilan proses pemberdayaan masyarakat yang dilaksanakan. Dengan demikian Hipotesis 3 yaitu, Partisipasi Masyarakat dalam Pemberdayaan melalui CSR Perusahaan (X3) berpengaruh positif terhadap Proses Pemberdayaan Masyarakat melalui CSR Perusahaan (X4) telah terjawab.

Dari data juga menunjukkan bahwa Proses Pemberdayaan memiliki pengaruh nyata positif terhadap Peningkatan Kesejahteraan Masyarakat (keberdayaan penilaian hasil pemberdayaan) sebesar 0,695 pada tingkat kesalahan sebesar $1 \%$. Hal ini dapat diartikan bahwa proses pemberdayaan masyarakat yang 
dilaksanakan oleh PT Agricon melalui program CSR telah meningkatkan Keberdayaan penilaian hasil. Dengan demikian Hipotesis 4 yaitu Proses Pemberdayaan Masyarakat melalui CSR Perusahaan (X4) berpengaruh positif terhadap Keberdayaan penilaian hasil pemberdayaan melalui CSR (Peningkatan Pendapatan) (Y).

\section{KESIMPULAN}

Kesimpulan yang dapat disampaikan dari hasil penelitian ini adalah sebagai berikut.

1. Pekerjaan utama peserta dalam program CSR PT Agricon tidak hanya petani tetapi juga peternak dan buruh tani. Meskipun demikian masih memiliki keterkaitan erat dengan program CSR PT Agricon.

2. Sebagian besar peserta memiliki pendidikan setingkat SLTA dan berusia rata-rata 42,16 Tahun. Sebagian besar peserta memiliki pendapat rendah (< Rp 1.500.000) hingga agak rendah (Rp 1.500.001 Rp 2.000.000). Rata-rata luasan lahan garapan peserta adalah 0,648 ha.

3. Konsep program CSR PT Agricon adalah pemberdayaan petani untuk kemandirian petani dalam berusahatani tanaman jagung sebagai bahan pakan ternak silase.

4. Program CSR PT Agricon (X1) berpengaruh positif terhadap Partisipasi Masyarakat dalam Pemberdayaan melalui CSR PT Agricon (X3) sebesar 0,561 dengan tingkat kesalahan $1 \%$.

5. Citra Perusahaan PT Agricon di Mata Masyarakat (X2) berpengaruh positif terhadap Partisipasi Masyarakat dalam Pemberdayaan melalui CSR PT Agricon (X3) sebesar 0,563 dengan tingkat kesalahan 1\%

6. Partisipasi Masyarakat dalam Pemberdayaan melalui CSR PT Agricon (X3) berpengaruh positif terhadap Proses Pemberdayaan Masyarakat melalui CSR PT Agricon (X4) sebesar 0,737 dengan tingkat kesalahan $1 \%$.

7. Proses Pemberdayaan Masyarakat melalui CSR PT Agricon (X4) berpengaruh positif terhadap Keberdayaan penilaian hasil pemberdayaan melalui CSR (Peningkatan Pendapatan) (Y) sebesar 0,695 dengan tingkat kesalahan $1 \%$.

\section{Saran}

1. Konsep program CSR yang digunakan oleh PT Agricon dalam 
memberikan bantuan cuma-cuma kepada petani dapat menjadi boomerang yang menciptakan ketergantungan petani. Akan lebih baik sekiranya bantuan yang diberikan juga disertakan persyaratan serta bimbingan yang dapat menghilangkan rasa ketergantungan petani.

2. Penelitian ini masih terbatas pada peningkatan kesejahteraan petani dalam arti sempit (peningkatan pendapatan), masih diperlukan penelitian lanjutan yang lebih mendalam mengenai dampak program CSR tersebut.

\section{DAFTAR PUSTAKA}

Gujarati, Damodar. 1999. Ekonometrika Dasar. Terjemahan Sumarno Zain. Jakarta: Erlangga.

Mapisangka A. 2009. Implementasi CSR terhadap Kesejahteraan Hidup Masyarakat. JESP. [Internet]. [diunduh 13 September 2015]. 1 (1), 39-47. Diunduh dari: http://fe.um.ac.id/wp-

content/uploads/2010/03/ANDI M -CSR.pdf

Morrison, F. B. 1961. Feeds and Feeding, Abridged. 9th ed. Morrison Publ. Co., Clinton, IA.

Saidi, Abidin. 2003. Sumbangan Sosial Perusahaan, Profil dan Pola Distribusinya di Indonesia: Survei 226 Perusahaan di 10 Kota. PIRAC. Jakarta. Ford Foundation. Singarimbun, Masri dan Sofian Effendi. 1995. Metode Penelitian Survei. Jakarta: LP3ES.

Solimun. 2002. Structural Equation Modeling Lisrel dan Amos. Malang: Universitas Negeri Malang.

Sugiyono. 2001. Metode Penelitian Bisnis. Bandung: Alfabeta.

Sukada S, Wibowo P, Ginano K, Jalal, Kadir I, Rahman T. 2007. Membumikan bisnis berkelanjutan memahami konsep \& praktik tanggung jawab sosial perusahaan. Jakarta [ID]: Indonesia Business Links. 
